J. Product. \& Dev., 11(1): 1-14 (2006)

\title{
EFFECT OF DIETARY ENERGY LEVELS ON PRODUCTIVE AND REPRODUCTIVE PERFORMANCE OF BUFFALO COWS.
}

\author{
H. El-Matarawy ${ }^{1}$ and M. A. Sarhan ${ }^{2}$ \\ 1- Animal Production Research Institute, Agricultural Research Center, \\ Ministry of Agriculture, Egypt. \\ 2- Department of Animal Production, Institute of Efficient Productivity, \\ Zagazig University, Egypt.
}

\begin{abstract}
:
The present study was designed to investigate the effect of three energy levels on the performance of Egyptian buffaloes. Eighteen pregnant buffalo cows six years old in the $3^{\text {rd }}$ season of lactation and weighing on the average $561.06 \pm 20.96 \mathrm{~kg}$ (at the last three months of pregnancy) were divided randomly into three similar groups. The experimental rations were isonitrogenous with three levels of energy $(100,80$ and $120 \%$ TDN). The first group served as control and animals were fed ration (R1) containing CFM $45.22 \%$, yellow corn $27.82 \%$ and berseem hay $26.96 \%$. The second group was fed ration (R2) containing CFM $45.73 \%$, yellow corn $25.12 \%$ and berseem hay. The third group was fed ration (R3) containing CFM 41.84\%, yellow corn $31.59 \%$ and berseem hay 26.57\%. Digestibility trial was conducted at the end of the experiment using three animals from each group.
\end{abstract}

\section{The results showed that:}

Buffaloes fed $80 \%$ dietary energy level recorded lower digestibility values of DM, OM, CP, CF, EE and NFE than those fed 100 and $120 \%$ levels. The nutritive values as TDN or DCP for all groups were quite similar. Animal fed $120 \%$ dietary energy level recorded heavier calf birth weight than those fed 100 and $80 \%$ energy levels with no significant differences. Animals fed $120 \%$ energy level recorded lower $(P<0.01)$ time lapsed to placenta expulsion $(h)$, interval from calving to uterine horns symmetry and cervical closure (days), as well as number of cervices per conception than those fed 100 and $80 \%$ energy levels. Interval from calving to complete uterine involution, to the first estrus and calving intervals (days) for animals fed $120 \%$ energy level were significantly $(P<0.01)$ shorter than that fed 80 and $100 \%$ energy levels. Buffaloes fed $120 \%$ energy level conceived 26.2 and 62.17 days earlier than those fed $80 \%$ and $100 \%$ energy level, respectively. The differences in days open were significant $(P<0.01)$. Milk yield and fat, protein, lactose, total solids, solid not fat and ash as a percent for buffaloes fed $120 \%$ energy level were significantly higher $(P<0.01)$ than those fed100 and $80 \%$ dietary energy levels. The animals received $120 \%$ dietary energy level recorded highest $(P<0.01)$ progesterone $(\mathrm{ng} / \mathrm{ml})$ and 17-estradiol $(\mathrm{pg} / \mathrm{ml})$ than those fed 100 and $80 \%$ energy levels. Progesterone concentration increased slightly up to 15 days postpartum and 
decreased at 20 days then it increased up to 35 days postpartum. However, 17estradiol concentration $(\mathrm{pg} / \mathrm{ml})$ behaved in an opposite trend,

Key words: Buffaloes, reproductive, digestibility, progesterone 17-estradiol, energy.

\section{INTROPDUCTION}

Buffaloes are the most important farm animals in Egypt. They contribute about 65 $\%$ of total milk yield in Egypt. (Marghany et al., 2001). Average total milk yield ranged between 1404 and $1836 \mathrm{~kg}$ per head in lactating season (302 days) with average fat content was about $7 \%$ and the production life of the lactating buffaloes was estimated to be 5 lactation seasons (Nigm, 1996).

Many factors have been shown to affect fertility in pre and post-partum of dairy buffaloes and dairy cattle, including delayed onset of ovarian cyclicity, bacterial complications of uterine involution, circulating progesterone level in already cyclic cows and quality of oocytes. Energy balance appears to be the most important factor, but the complex interactions of all these factors must be considered and controlled in order to improve the understanding and to develop new strategies to enhance fertility of dairy buffaloes and cows (Huszenicza et al., 2004).

Nutrition is the major factor affecting the physiological and metabolic status of animals. Many experiments had been carried out to study the effect of energy and protein levels on milk yield and composition. There is general agreement that an increase in energy intake of dairy cows within certain limits, increase milk yield, solids not fat (SNF) and to a lesser extent lactose and decrease milk fat (Gordon and Forbes, 1970). Birth weight of calves is significantly increased when their dams are maintained on high level of feeding during late pregnancy (Bellows and Short, 1987 and Bayoumi, 1995). Increasing energy and protein levels in the diet to $115 \%$ improved the body condition and increased body fat within the range considered optimal for this breed. No adverse effect on the reproductive parameters were observed, except for age at first calving which had a favourable effect on the dairy performance over the first 100 days of lactation (Bilik et al., 2004).

Calf birth weight, placenta weight and fetus liquid weight increased with increasing feeding level from 100 to $120 \%$ dietary energy levels (Kirrella, 1984; Houghton et al., 1990 and Bayoumi , 1995). Shorter days open for buffaloes fed $120 \%$ energy level of Ghoneim allowances (1967) during prepartum period than those fed 100 $\%$ energy level. Milk yield increased with increasing energy level (Sharma et al., 1993; Aaes et al., 1994; Bayoumi, 1995; Mcdonald et al., 1995 and Ekinci and Broderick, 1997 and El-Ashry et al., 2003). The present study was designed to investigate the effect of energy levels on the reproductive performance and digestibility of nutrients Egyptian buffaloes. 


\section{MATERIAL AND METHODS}

This study was conducted at El-Gemiza Experimental Station belonging to Animal Production Research Institute, Agriculture Research Center, Ministry of Agriculture, Egypt, during the period from April 2002 up to June 2003.

Eighteen pregnant buffaloes six years old in the $3^{\text {rd }}$ season of lactation and weighing on the average $561.06 \pm 20.96 \mathrm{~kg}$ (at the last three months of pregnancy) were divided randomly into three similar groups (six animal each). The experimental animals were kept under semi-open shaded pens. The experimental rations were isonitrogenous with three levels of energy (100, 80 and 120\% TDN according to Kearl, 1982). The experimental rations consisted of concentrate feed mixture (CFM) and yellow corn (as concentrate source) and berseem hay and rice straw (as roughage source). Concentrate: roughage ratio was about 1: 1 . The first group served as control and animals were fed ration (R1) containing CFM $5.20 \mathrm{~kg}(45.22 \%)$, yellow corn3.2 $\mathrm{kg}(27.82 \%)$ and berseem hay $3.10 \mathrm{~kg}(26.96 \%)$. The second group was fed ration (R2) containing CFM $4.55 \mathrm{~kg}(45.73 \%)$, yellow corn $2.50 \mathrm{~kg}(25.12 \%)$ and berseem hay $2.90 \mathrm{~kg}(29.15 \%)$. The third group was fed ration (R3) containing CFM $5.59 \mathrm{~kg}$ (41.84\%), yellow corn $4.22 \mathrm{~kg}(31.59 \%)$ and berseem hay $3.55 \mathrm{~kg}(26.57 \%)$. Ingredients, chemical composition of the experimental rations and chemical composition of the feedstuffs are shown in Tables 1 and 2. The experimental rations were formulated to cover maintenance and production allowance according to Kreal (1982). The rations were offered twice daily at 7.0 a.m. and 4.0 p.m. In addition water was offered three times daily during summer season and twice during winter season. Animals were weighted at the beginning of the experiment to the nearest $\mathrm{kg}$, while weight of dams and newborn calves were recorded immediately after calving. Uterine and ovarian palpation per rectum to determine the uterine involution was performed weekly from the first week after parturition until mating. The first observed estrus and number of services per conception were recorded for each buffalo. Number of days open was calculated for buffaloes that were actually diagnosed pregnant. Buffaloes were hand milked twice daily at 7.0 a.m. and 4.0 p.m. and daily milk yield of each animal was recorded from 50 days postpartum up to 150 days postpartum period. Representative samples of milk (morning and evening samples) were mixed by ratio of $1 \%$ weight of milk yield and analyzed biweekly for fat, lactose, protein, total solids and ash with using Milkoscan apparatus.

Digestibility trial was conducted at the end of the experiment by using three animals in each experimental group. A grab sample method was applied using acid insoluble ash (AIA) technique as internal marker according to Van Keulen and Young (1977). Fecal grab samples were collected for four successive days from each animal. Chemical composition of the different ingredients, experimental rations and feces samples were analyzed according to A. O.A. C. (1995) procedures. 
Table 1. Chemical composition of experimental rations with different levels of energy by buffalo cows.

\begin{tabular}{cccc}
\hline Items & Rations 1 & Rations 2 & Rations 3 \\
\hline DM & 87.89 & 86.25 & 88.65 \\
OM & 89.12 & 87.25 & 90.56 \\
CP & 12.55 & 12.49 & 12.64 \\
CF & 18.87 & 20.17 & 16.71 \\
EE & 2.11 & 1.86 & 2.31 \\
NFE & 55.59 & 51.73 & 58.9 \\
ASH & 13.75 & 13.75 & 9.44 \\
\hline
\end{tabular}

- $\quad$ The ingredients of concentrate feed mixture (CFM) were undecorticeted cotton seed meal $36 \%$, yellow $25 \%$, rice bran $5 \%$ wheat bran $28 \%$, limestone $2 \%$, salt $1 \%$ and molasses $3 \%$.

Table 2. Chemical composition of feedstuffs as DM basis used in the experimental rations for buffalo cows.

\begin{tabular}{lccccccc}
\hline \multirow{2}{*}{ Feedstuffs } & \multicolumn{7}{c}{ Nutrient \%as DM } \\
\cline { 2 - 8 } & DM & OM & CP & CF & EE & NFE & Ash \\
\hline CFM & 87.27 & 94.62 & 17.56 & 9.17 & 1.19 & 66.70 & 5.35 \\
Yellow corn & 89.17 & 98.44 & 9.05 & 2.39 & 2.88 & 84.12 & 1.57 \\
Berseem hay & 92.96 & 87.44 & 13.93 & 27.32 & 0.48 & 45.71 & 12.56 \\
\hline
\end{tabular}

Blood samples were collected at five days interval after parturition until 35 days postpartum, via the jugular vein of buffaloes into glass tube and serum was separated by centrifugation at 3000 r.p.m for 10 minutes, then cooled and kept frozen at $-20{ }^{\circ} \mathrm{C}$ until being assayed for concentration of serum progesterone and 17-estradiol. Direct radioimmiunoassy technique was performed for progesterone and 17-estradiol of representative samples. Kits of Diagnostic Products Corporation Los Angles U.S.A. with ready antibody coated tubes were used according to the procedure outlined by the manufacture.

\section{Statistical analysis:}

Data were statistically examined by analysis of variance (ANOVA) according to Snedecor and Cochran (1982) using SPSS system (1998). Conception rate was analysed by using $\chi^{2}$ test. The differences among means were tested by using Duncan's New Multiple Range test, Duncan (1955). 


\section{RESULTS AND DISCUSSION}

\section{Nutrient digestibility:}

Data in Table (3) clearly show that buffaloes fed $80 \%$ dietary energy levels recorded lower digestibility values of DM, OM, CP, CF, EE and NFE than those fed 100 and $120 \%$ levels. The differences were significant $(\mathrm{P}<0.05$ or $\mathrm{P}<0.01)$ for $\mathrm{OM}$, $\mathrm{EE}$ and NFE digestibility and were not significant for DM, CP and CF digestibility. Also, data clearly indicate that animals fed $120 \%$ dietary energy levels recorded higher digestibility values of DM, CP and NFE than those fed $100 \%$ levels. However, the nutritive values as TDN or DCP for all groups were similar and the differences were not significant. These results are in agreement with those reported by El-Ashry et al. (2003) who found that the animals fed $120 \%$ dietary energy level recorded higher digestibility values of DM, OM, CP, CF, EE and NFE than those fed 100\% level. Also, Kumar et al. (1981) and Etman (1985) reported that the increase of dietary energy levels improved the digestibility of all nutrients except $\mathrm{CF}$ digestibility with male buffaloes calves. While Hossain et al. (2003b) found that, OM and CF digestibility $(\mathrm{P}<0.05)$ increased with increasing dietary energy levels for goats, but DM, CP, NFE and EE was similar for all dietary energy levels. Moreover, Hossain et al. (2003a) with sheep, reported that $\mathrm{DM}, \mathrm{OM}, \mathrm{CF}$ digestibility increased $(\mathrm{P}<0.05)$ with increasing dietary energy level. However, CP, NFE and EE was similar for all dietary energy levels. In this respect, ElBanna (1995) reported that increasing levels of dietary energy increased the digestibility of DM, OM and CP while decreased CF digestibility for sheep, goats and camel.

\section{Reproductive parameters:}

Data in Table (4) clearly indicate that animal fed $120 \%$ dietary energy level recorded higher average of birth weight of newly born calves than those claved to animals fed 100 and $80 \%$ dietary energy levels with no significant differences.

The obtained results also, indicate that animals fed $120 \%$ dietary energy level recorded lower $(\mathrm{P}<0.01)$ time /lapsed to placenta expulsion $(\mathrm{h})$ than those fed 100 and $80 \%$ dietary energy levels. The interval from calving to uterine horns symmetry in animals fed $120 \%$ dietary energy level was lower $(\mathrm{P}<0.01)$ than those fed 100 and 80 $\%$ dietary energy levels. The interval from calving to complete uterine involution in animals fed $120 \%$ dietary energy level was 15.67 days was being significantly ( $\mathrm{P}<$ 0.01 ) shorter than that fed 80 and $100 \%$ dietary energy levels. Moreover, the uterine involution in animals fed $80 \%$ dietary energy level showed longer days $(\mathrm{P}<0.01)$ than those fed $100 \%$ dietary energy level (control). Time to the cervical closure (days) was shorter $(\mathrm{P}<0.01)$ for buffaloes fed $120 \%$ dietary energy level than those fed 100 and $80 \%$ dietary energy levels. Buffaloes fed $120 \%$ dietary energy level also showed significantly shorter $(\mathrm{P}<0.01)$ interval from calving up to the first estrus compared to the other groups fed $100 \%$ and $80 \%$ dietary energy levels. 
Table 3. Nutrient digestibilities and nutritive values of the experimental rations fed by buffalo cows.

\begin{tabular}{|c|c|c|c|c|}
\hline \multirow[t]{2}{*}{ Traits } & \multicolumn{3}{|c|}{ Energy levels } & \multirow[t]{2}{*}{ Sig. } \\
\hline & $100 \%$ & $80 \%$ & 120 & \\
\hline Animal weight kg & $563.33 \pm 42.03$ & $562.0 \pm 36.21$ & $557.83 \pm 37.42$ & NS \\
\hline Animal weight $\mathrm{W}^{0.75}$ & $115.33 \pm 6.49$ & $115.19 \pm 5.65$ & $114.61 \pm 5.88$ & NS \\
\hline \multicolumn{5}{|l|}{ Digestion coefficient (\%) } \\
\hline DM & $65.83 \pm 2.80$ & $59.38 \pm 2.88$ & $66.89 \pm 0.89$ & NS \\
\hline $\mathrm{OM}$ & $73.50 \pm 2.23^{a}$ & $63.35 \pm 1.36^{\mathrm{b}}$ & $68.95 \pm 1.20^{\mathrm{ab}}$ & $* *$ \\
\hline $\mathrm{CP}$ & $71.23 \pm 2.15$ & $66.23 \pm 1.31$ & $71.98 \pm 1.91$ & NS \\
\hline $\mathrm{CF}$ & $56.02 \pm 2.65$ & $57.61 \pm 1.94$ & $53.90 \pm 1.71$ & NS \\
\hline $\mathrm{EE}$ & $73.15 \pm 1.52^{\mathrm{a}}$ & $66.06 \pm 2.14^{\mathrm{b}}$ & $72.65 \pm 1.50^{\mathrm{a}}$ & $*$ \\
\hline NFE & $69.69 \pm 1.16^{\mathrm{a}}$ & $60.48 \pm 0.83^{b}$ & $70.49 \pm 0.47^{\mathrm{a}}$ & $* *$ \\
\hline \multicolumn{5}{|l|}{ Nutritive values \%: } \\
\hline TDN & $59.84 \pm 2.89$ & $55.69 \pm 1.58$ & $59.24 \pm 1.66$ & NS \\
\hline DCP & $8.87 \pm 0.29$ & $8.31 \pm 0.16$ & $8.99 \pm 2.24$ & NS \\
\hline \multicolumn{5}{|l|}{ Nutritive values as: } \\
\hline TDN/head /kg/day & $0.11 \pm 0.005$ & $0.10 \pm 0.003$ & $0.11 \pm 0.003$ & NS \\
\hline TDN/head $/\left(\mathrm{W}^{0.75}\right) \mathrm{kg} /$ day & $0.52 \pm 0.03$ & $0.48 \pm 0.01$ & $0.52 \pm 0.01$ & NS \\
\hline DCP / head $/ \mathrm{kg} /$ day & $0.015 \pm 0.0005$ & $0.015 \pm 0.0003$ & $0.016 \pm 0.0004$ & NS \\
\hline DCP/head $\left(\mathrm{W}^{0.75}\right) \mathrm{kg} /$ day & $0.08 \pm 0.003$ & $0.07 \pm 0.001$ & $0.08 \pm 0.003$ & NS \\
\hline
\end{tabular}

Means in the same row with different letter differ significantly $(\mathrm{P}<0.05)$.

$*=\mathrm{P}<0.05, * *=\mathrm{P}<0.01$ and N.S. $=$ Not significant.

The present results showed that buffaloes fed $120 \%$ dietary energy level conceived 26.2and 62.17 days fed $100 \%$ and fed $80 \%$ dietary energy level, respectively. The differences in this respect were significant $(\mathrm{P}<0.01)$. Also, the present data show that the number of services per conception for animals fed $120 \%$ dietary energy level (1.17) was insignificantly lower than the control group (1.5.) and those fed $80 \%$ dietary energy level (2.00). ) Conception rate of buffaloes fed on 100, 80 and $120 \%$ energy levels was $50 \%, 0.0 \%$ and $100 \%$ within the last 60days after calving. The remainder $50 \%$ of the buffalo cows of the first group conceived from 60 to 90 days after calving versus $33 \%$ in the second group. The remaining $67 \%$ of buffalo cows fed $80 \%$ energy level conceived after 90 days (from 90 to 120 days). Gestation length and calving intervals (days) were significantly $(\mathrm{P}<0.01)$ shorter for buffaloes fed $120 \%$ dietary energy level than those fed 100 and $80 \%$ dietary energy levels. These results are in agreement with those obtained by Hung et al. (1993), Youssef et al. (1998), ElGaafarawy et al. (2003) and El-Ashry et al. (2003) who found that birth weight of calves didn't reflected by the level of nutrition, but rather maternal body weight during pregnancy. Khan et al. (2004) found that birth weight of calves in the low-energy group was lower $(\mathrm{P}<0.05)$ than that of calves in the high-energy group. Cows that were 
Table 4: Effect of dietary energy levels on reproductive performance of buffalo cows, under Egyptian conditions.

\begin{tabular}{|c|c|c|c|c|}
\hline \multirow[t]{2}{*}{ Traits } & \multicolumn{3}{|c|}{ Energy levels } & \multirow[t]{2}{*}{ Sig. } \\
\hline & $100 \%$ & $80 \%$ & 120 & \\
\hline Number of animals & 6 & 6 & 6 & \\
\hline Body weight of buffaloes (kg) & $563.33 \pm 42.03$ & $562.0 \pm 36.21$ & $557.83 \pm 37.42$ & NS \\
\hline Body weight of buffaloes ( $\left.W^{0.75}\right)$ & $115.33 \pm 6.49$ & $115.19 \pm 5.65$ & $114.61 \pm 5.88$ & NS \\
\hline Calf weight at birth (kg) & $36.00 \pm 0.73$ & $36.67 \pm 1.84$ & $36.83 \pm 1.40$ & NS \\
\hline Time/lapsed to placenta expulsion (h) & $7.50 \pm 0.50^{\mathrm{a}}$ & $7.83 \pm 1.56^{\mathrm{a}}$ & $4.08 \pm 0.51^{\mathrm{b}}$ & $* *$ \\
\hline Uterine horns symmetry (days) & $31.33 \pm 1.33^{\mathrm{b}}$ & $37.67 \pm 1.09^{\mathrm{a}}$ & $21.83 \pm 1.33^{\mathrm{c}}$ & $* *$ \\
\hline Uterine involution (days) & $22.83 \pm 0.54^{\mathrm{b}}$ & $28.00 \pm 0.26^{\mathrm{a}}$ & $15.67 \pm 0.33^{c}$ & $* *$ \\
\hline Cervical closure (days) & $28.83 \pm 0.31^{\mathrm{b}}$ & $35.50 \pm 0.43^{\mathrm{a}}$ & $24.67 \pm 1.91^{\mathrm{c}}$ & $* *$ \\
\hline First postpartum estrus (days) & $42.83 \pm 0.91^{\mathrm{b}}$ & $66.33 \pm 1.71^{\mathrm{a}}$ & $36.00 \pm 0.26^{\mathrm{c}}$ & $* *$ \\
\hline Service periods (days) & $21.33 \pm 0.33$ & $35.17 \pm 0.55$ & $22.00 \pm 0.05$ & NS \\
\hline Number of services per conception & $1.50 \pm 0.22$ & $2.00 \pm 0.37$ & $1.17 \pm 0.17$ & NS \\
\hline Days open (days) & $55.50 \pm 4.48^{b}$ & $101.50 \pm 5.10^{\mathrm{a}}$ & $39.33 \pm 3.34^{c}$ & $* *$ \\
\hline Gestation length (days) & $316.50 \pm 0.67^{\mathrm{a}}$ & $316.33 \pm 0.42^{\mathrm{a}}$ & $313.50 \pm 0.96^{b}$ & $* *$ \\
\hline Calving interval (days) & $370.00 \pm 4.95^{\mathrm{a}}$ & $417.83 \pm 5.19^{\mathrm{a}}$ & $356.17 \pm 3.88^{b}$ & $* *$ \\
\hline
\end{tabular}

Means in the same row with different letter differ significantly $(\mathrm{P}<0.05)$.

$* *=\mathrm{P}<0.01$ and N.S. $=$ Not significant.

on low pre-calving dietary energy level produced less milk during lactation than the cows in the high energy precalving group. No significant difference was noticed on reproductive parameters of cow. While, Kirrella (1984), Houghton et al.(1990) and Bayoumi (1995) reported that calf birth weight increased with increasing feeding level from 100 to $120 \%$. Also, Bayoumi (1995) and El-Ashry et al. (2003) obtained shorter days open for buffaloes fed $120 \%$ dietary energy level of Ghoneim allowances (1967) during postpartum period than those fed $100 \%$ dietary energy level. Mansour et al. (2000) showed that the level of dietary energy has a significant effect on the onset and duration of oestrus, ovarian activity and quality of embryos available for transfer and it increased the number of unovulatory ovarian follicles in goats. However, Abecia et al. (1997) found no effect of dietary energy level on pregnancy rate for Rasa Aragonesa ewes.

\section{Milk yield and its composition:}

Results obtained in Table (5) showed that milk yield and fat, protein, lactose, total solids, solid not fat and ash as percentage and daily yield $(\mathrm{kg})$ for buffaloes fed 120 
$\%$ dietary energy level was significantly higher $(\mathrm{P}<0.01)$ than those recorded for buffaloes fed 100 and $80 \%$ dietary energy levels. This might be due to the increase in nutrients for $120 \%$ dietary energy levels group (Table 3). These results are in good agreement with those reported by Sharma et al. (1993), Aaes et al. (1994), Bayoumi (1995), McDonald et al. (1995), Ekinci and Broderick (1997), Adogla-Bessa and Aganga (2000) and El-Ashry et al. (2003) who concluded that milk yield increased with increasing dietary energy level. Also, Broderieck (2003) showed an increasing dietary energy by reducing forage improved milk yield and efficiency in dairy cows. LeeMeichu et al. (2003a and b) found that milk yields of the dairy goats fed on low and mid-dietary energy levels were higher $(\mathrm{P}<0.05)$ than those fed on a high dietary energy level. The milk composition, the percentage of milk protein, milk fat, the content of lactose, total solids and the urea nitrogen content in milk did not significantly differe among all the treatments. However, Al-Totanji and Lubbadeh (2000) found that milk production before weaning was significantly $(\mathrm{P}<0.05)$ higher for groups of goats fed intermediate and high energy rations than that for goats fed low energy ration during the prepartum period. Data of 7\% FCM yield are in parallel with their corresponding values of milk yield. Similar results were obtained by El-Ashry et al. (2003). However, ElSerafy et al. (1984) observed higher 7\% FCM yield was highest for lactating buffaloes received $80 \%$ of NRC (1978) energy allowances compared with those received 100 and $120 \%$ dietary energy levels.

\section{Serum progesterone and 17-estradiol concentration:}

Data in Table (6) show that animals received $120 \%$ dietary energy level recorded higher $(\mathrm{P}<0.01)$ values of progesterone $(\mathrm{ng} / \mathrm{ml})$ and 17 -estradiol $(\mathrm{pg} / \mathrm{ml})$ concentration than that the animals fed 100 or $80 \%$ dietary energy levels.

The present results show that progesterone concentration increased slightly up to 15 days postpartum and decreased at 20 days then increased up to 35 days postpartum. However, 17-estradiol concentration $(\mathrm{pg} / \mathrm{ml})$ behaved opposite trend, it decreased slightly from 5 days up to 15 days and increased at 20 days then decreased up to 35 days postpartum. No significant interactions were detected between the studied factors (dietary energy levels and postpartum period). This reveals that the effects of dietary energy levels on progesterone and 17-estradiol behaved in the same pattern during postpartum periods. Mansour et al. (2000) showed that the level of estradiol-17 beta was at a peak level on the day of oestrus. It then decreased to its lowest values on the day of embryo recovery.

It be concluded that buffaloes fed ration containing 120\% dietary energy levels during the late pregnancy and during lactating period improved reproductive performance and digestibility of nutrients without any adverse effect on performance of buffaloes. 
Table 5: Effect of dietary energy levels on milk yield and composition of buffalo cows, under Egyptian conditions.

\begin{tabular}{|c|c|c|c|c|}
\hline \multirow[t]{2}{*}{ Traits } & \multicolumn{3}{|c|}{ Energy levels } & \multirow[t]{2}{*}{ Sig. } \\
\hline & $100 \%$ & $80 \%$ & $120 \%$ & \\
\hline Milk production (yield/day) & $8.17 \pm 0.49^{b}$ & $7.58 \pm 0.42^{b}$ & $9.58 \pm 0.35^{\mathrm{a}}$ & $* *$ \\
\hline $7 \%$ FCM yield (kg/day) ${ }^{1}$ & $8.26 \pm 0.46^{\mathrm{b}}$ & $7.16 \pm 0.36^{\mathrm{b}}$ & $10.05 \pm 0.45^{\mathrm{a}}$ & $* *$ \\
\hline Fat $\%$ & $7.13 \pm 0.20^{\mathrm{a}}$ & $6.48 \pm 0.12^{b}$ & $7.45 \pm 0.11^{\mathrm{a}}$ & $* *$ \\
\hline Fat yield (kg/day) & $0.58 \pm 0.03^{\mathrm{b}}$ & $0.49 \pm 0.02^{b}$ & $0.72 \pm 0.03^{\mathrm{a}}$ & $* *$ \\
\hline Protein \% & $4.00 \pm 0.07^{\mathrm{a}}$ & $3.60 \pm 0.15^{b}$ & $4.25 \pm 0.06^{\mathrm{a}}$ & $* *$ \\
\hline Protein yield (kg /day) & $0.33 \pm 0.02^{b}$ & $0.27 \pm 0.02^{b}$ & $0.41 \pm 0.02^{\mathrm{a}}$ & $* *$ \\
\hline Lactose $(\%)$ & $4.85 \pm 0.08^{\mathrm{ab}}$ & $4.62 \pm 0.14^{b}$ & $5.03 \pm 0.03^{\mathrm{a}}$ & $* *$ \\
\hline Lactose Yield (kg /day) & $0.40 \pm 0.02^{\mathrm{ab}}$ & $0.38 \pm 0.04^{b}$ & $0.48 \pm 0.02^{\mathrm{a}}$ & $* *$ \\
\hline Total solid (\%) & $16.42 \pm 0.21^{\mathrm{a}}$ & $15.30 \pm 0.16^{\mathrm{b}}$ & $16.70 \pm 0.49^{\mathrm{a}}$ & $* *$ \\
\hline Total solids yield (kg/day) & $1.34 \pm 0.08^{b}$ & $1.16 \pm 0.07^{b}$ & $1.60 \pm 0.08^{\mathrm{a}}$ & $* *$ \\
\hline Solid not fat $(\%)$ & $9.28 \pm 0.09^{\mathrm{ab}}$ & $8.78 \pm 0.24^{b}$ & $9.72 \pm 0.17^{\mathrm{a}}$ & $* *$ \\
\hline Solid not fat yield (kg /day) & $0.76 \pm 0.05^{b}$ & $0.67 \pm 0.05^{b}$ & $0.93 \pm 0.03^{\mathrm{a}}$ & $* *$ \\
\hline $\operatorname{Ash}(\%)$ & $0.61 \pm 0.004$ & $0.61 \pm 0.008$ & $0.61 \pm 0.004$ & NS \\
\hline Ash yield (kg /day) & $0.05 \pm 0.003^{\mathrm{b}}$ & $0.05 \pm 0.003^{b}$ & $0.06 \pm 0.002^{\mathrm{a}}$ & $* *$ \\
\hline
\end{tabular}

${ }^{1} 7 \%$ FCM was calculated as: $0.265 \mathrm{x}$ milk fat $(\mathrm{kg})+10.5 \mathrm{x}$ fat yield, according to Raafat and Salah (1962).

Means in the same row with different letter differ significantly $(\mathrm{P}<0.05)$.

$$
* *=\mathrm{P}<0.01
$$

N.S . = Not significant. 
Table 6: Effect of dietary energy levels and postpartum periods (days) on progesterone and 17-estradiol hormones of buffalo cows, under Egyptian conditions.

\begin{tabular}{lcc}
\hline Items & $\begin{array}{c}\text { Progesterone } \\
(\mathbf{n g} / \mathbf{m l})\end{array}$ & $\begin{array}{c}\text { 17- estradiol } \\
(\mathbf{p g} / \mathbf{m l})\end{array}$ \\
\hline Effect of energy levels (A): & & \\
$100 \%$ & $1.50 \pm 0.26^{\mathrm{b}}$ & $1.58 \pm 0.25^{\mathrm{b}}$ \\
$80 \%$ & $0.22^{\mathrm{b}} \pm 1.53$ & $1.50 \pm 0.23^{\mathrm{b}}$ \\
$120 \%$ & $2.05 \pm 0.27^{\mathrm{a}}$ & $1.90 \pm 0.29^{\mathrm{a}}$ \\
Sig. & $* *$ & $* *$ \\
Effect of postpartum periods (B): & & \\
5 days postpartum & $0.69 \pm 0.08^{\mathrm{f}}$ & $3.96 \pm 0.17^{\mathrm{a}}$ \\
10 days postpartum & $1.12 \pm 0.14^{\mathrm{e}}$ & $1.89 \pm 0.13^{\mathrm{c}}$ \\
15 days postpartum & $1.87 \pm 0.17^{\mathrm{c}}$ & $0.63 \pm 0.09^{\mathrm{ef}}$ \\
20 days postpartum & $0.53 \pm 0.05^{\mathrm{f}}$ & $2.23 \pm 0.16^{\mathrm{b}}$ \\
25 days postpartum & $1.44 \pm 0.14^{\mathrm{d}}$ & $1.51 \pm 0.11^{\mathrm{d}}$ \\
30 days postpartum & $2.20 \pm 0.14^{\mathrm{b}}$ & $0.91 \pm 0.09^{\mathrm{e}}$ \\
35 days postpartum & $4.01 \pm 0.15^{\mathrm{a}}$ & $0.50 \pm 0.06^{\mathrm{f}}$ \\
Sig. & $* *$ & $* *$ \\
Interaction: & & $\mathrm{NS}$ \\
A x B & $\mathrm{NS}$ & \\
\hline
\end{tabular}

Means in the same column with different letter differ significantly $(\mathrm{P}<0.05)$.

$* *=\mathrm{P}<0.01$ and N.S. $=$ Not significant.

\section{REFFRENCES}

Aaes, O.; Anderson, J. B. and Ingvatsen, K. L. (1994). Energy level and strategy of feeding for dairy cows in dry period. 1. Effect on milk production, feed intake, daily weight gain and health in early lactation. Forskingsr apport. Fra-Statenshusdyrugsf or Sog.1994 No. 22, 22pp.

Abecia,J.A.; Lozano,J.M.; Forcada, F. and Zarazaga, L. (1997). Effect of level of dietary energy and protein on embryo survival and progesterone production on day eight of pregnancy in Rasa Aragonesa ewes. Animal Reproduction Science, 48(2/4): 209-218

Adogla-Bessa, T. and Aganga, A. A . (2000). Milk production of Tswana goats fed diets containing different levels of energy. South African Journal of Animal Science, 30(1): 77-81.

Al-Totanji, W. and Lubbadeh, W. (2000). Effect of feeding different levels of energy and protein during the last two months of gestation on Shami goats performance in Jordan Valley. Dirasat Agricultural Sciences, 27(2): 165-175

A. O. A. C. (1995). Official Methods of Analysis. $15^{\text {th }}$ ed. Association of Official Analytical Chemists. Washington, Virginiall, USA. 
Bellows, R.A. and Short, R. E. (1978). Effect of precalving feed level on birth weight, calving difficulty and subsequent fertility. J. Anim Sci., 46:1522.

Bayoumi, H. M. (1995). Productive and reproductive performance of Egyptian buffaloes as affected by feeding level during mid-pregnancy and early stage of lactation. M. Sc. Thesis, Fac. of Agric., Moshtohor, Zagazig Univ., Banha Branch, Egypt.

Bilik,K.; Strzetelski, J.; Niwinska, B. and Osiegowski, S. (2004). Assessment of reproductive and dairy performance, body condition and fatness in Black-and-White heifers fed different energy and protein levels. Annals of Animal Science, 4(1): 109124 .

Broderick,G.A. (2003). Effects of varying dietary protein and energy levels on the production of lactating dairy cows. Journal of Dairy Science, 86(4): 1370-1381.

Duncan, D. B. (1955). Multiple range and multiple F. test. Biometrics. II. 1-42.

Ekinci, C. and Broderick, G. A. (1997). Effect of processing high moisture corn on rumenal fermentation and milk yield. J. Dairy Sci., 80: 3298.

El-Ashry, M. A.; Khattab, H. M.; Etman, K. E. I. And Sayed, S. K. (2003). Effect of two different energy and protein levels on productive and reproductive performance of lactating buffaloes. Egyptian J. Nutrition and feeds, 6 (Special Issue): 491-506.

El-Banna, H. M. (1995). Effect of dietary energy, protein and their interaction on nutrient utilization by sheep, goats and camels. Camle-Newsletter. (11): 16-18.

El-Gaafarawy, A, M.; Zaki, A. A.; Enas, El-Sedfy, R. and El-Ekhnawy, Kh. (2003). Effect of feeding Nagella sativa cake on digestibility, nutritive value, reproductive performance of Friesian cows and immuno activity of their offspring Egyptian $J$. Nutrition and feeds, 6 (Special Issue): 539-549.

El-Serafy, A.M.; Khattab, H. M.: El-Ashry, M. A. ; Soliman, H. S.; Allam, S. M. ; Aly, H. M and Gado, H. (1984). NRC- energy allowance for milking buffaloes: Effect on lactation performance Milk composition and some blood traits. Egypt. J. Anim. Prod., 24: 127.

Etman, K. E. I. (1985). The effect of level concentrate feeding and roughage on meat production. Ph. D Thesis Fac. Aagric.Zagazig Univ.

Ghoneim, A. (1967). Animal Nutrition. $6^{\text {th }}$ Ed Anglo Egyptian library, Cairo (In Arabic).

Gordon, F. J. and Forbes, J. J. (1970). The associative effect of level of energy and protein intake in the dairy cow. J. Dairy Res., 37:481.

Hossain, M. E.; Shahjalal, M.; Khan, M.J. and Bhuiyan, A. A. (2003a).Effect of dietary energy supplementation on feed intake, growth and reproductive performance of sheep under grazing condition. Pakistan Journal of Nutrition, 2(3): 148-152

Hossain, M.E.; Shahjalal, M.; Khan, M. J. and Hasanat, M. S. (2003b). Effect of dietary energy supplementation on feed intake, growth and reproductive performance of goats under grazing condition. Pakistan Journal of Nutrition, 2(3): 159-163

Houghton, P. L.; Lemenager, R. P.; Horstman, L. A.; Hendeix, K. S. and Moss, G. E. (1990). Effect of body composition, per and postpartum energy level and early weaning on reproductive performance of beef cows and weaning calf gain. J. Anim. Sci., 68: 1438. 
Hung, Y. X.; Ji, Y. L.; Du, Z. Y.; Zhang, S. W.; Liu, M. X. Sun, X. G. and Dong, E. M. (1993). Nutrient requirements of beef cows in the last half of pregnancy. Acta Veterinariaet. Zootechnica. Sinica. , 24: 211-218.

Huszenicza, G.; Kulcsar,M.; Katai, L.; Balogh, O.; Samanc, H. and Ivanov, I. (2004). Postpartum resumption of cyclic ovarian function, first oestrus and reconception and their relation to energy metabolism in high-producing dairy cows. Veterinarski Glasnik, 58(1/2): 9-27

Kearl, L. (1982). Nutrient allawance of ruminants in developing countries. International feedstuffs Institute Utah Agricultural Experiment Station Utah State Univ. Logan Utah.

Khan, M.A.A.; Islam, M.N.; Khan, M.A.S. and Akbar, M.A. (2004). Effects of feeding high and low energy levels during late pregnancy on performance of crossbred dairy cows and their calves. Asian Australasian Journal of Animal Sciences, 17(7): 947953.

Kirrella, A. K. (1984). Effect of different level of feeding during gestation period on some physiological aspects in Friesian cows. Ph.D. Thesis, Tanta Univ., Egypt.

Kumar, N.; Singh, U. B and Verma, D. N. (1981). Effect of different levels of dietary protein and energy on growth of male bufflo calves. Indian J. Anim. Sci., 51 (5): 513-517.

Lee-MeiChu; Hwang-SenYuan; Chiou-WenShyg and Chiou, W.S.P. (2003a). Effect of dietary energy on the performance of midlactation dairy goats. Journal of Taiwan Livestock Research, 36(4): 327-335.

Lee-MeiChu; Hwang-SenYuan; Chiou-WenShyg and Chiou, W.S.P. (2003b). Effect of dietary energy on the performance of dry dairy goats. Journal of Taiwan Livestock Research, 36(4): 291-299 .

Mansour, M. M.; Hamam, A. M.; Hegazy, M.A. and Ezzo, O.H. (2000). Effect of dietary energy on the superovulatory response to PMSG treatment, with special reference to embryo quality, metabolic and endocrine response in female goats. Egyptian Journal of Veterinary Science, 34: 77-101.

Marghasny, M.; El-Tahan, A. A. H.; Moawd, R., I.; Zaki, A. A. and Ghanem, H. (2001). Effect of cotton plant silage supplementation on digestibility and milk production by dairy buffaloes. Proc. Of the $8^{\text {th }}$ Scientific Conf. On Animal Nutr. (2326 Oct.) 4: 365 Sarm El-Sheikh, Egypt.

McDonald, P.; Edwards, R. A. and Greenbolgh, J. F. D. (1995). Animal Nutrition. ( $^{\text {th }}$ edition). Oliver and Boyd Publisher.

Nigm, A. N. (1996). Characterization of Egyptian Buffalo. International Symposium on buffalo resources and production system.

NRC (1978). Nutrient requirements of dairy cattle. $3^{\text {rd }}$ revised Edition (1978). National Academy Press Washington, D. C.

Raaft, M. A. and Saleh, M. E. (1962). Efficiency of feed utilization with buffaloes and dairy cattle. Proceedings of the Sec. Aim. Prod. Conf. (march 3-10), Cairo. 
Sharma, A. K.; Takkar, O. R. and Chaudhary, K. C. (1993). Plasma production and milk production in Murrah (Bos bubalis) buffaloes fed with elevated energy levels during pre and postpartum period. Indian Journal of Animal Reproduction, 14: (1) $1-4$.

Snedecor, G. W. and Cochran, W. G. (1982). Statistical Methods. $7^{\text {th }}$ Edition, Iowa State University, Press Ames, USA.

SPSS (1998). SPSS User s Guide Statistics Version 8. Copyright SPSS lnc., USA.

Van Keulen, J. and Young, B. A. (1977). Evaluation of acid-insoluble ash as a natural marker in ruminant digestibility study. J. Anim. Sci., 44:282.

Youssef, M.M., Abdiene, A. M.; Khattab, R. M. and Darwish, S. A. (1998). Effect of feeding Nagella sativa cake on productive and reproductive performance of buffaloes. Egyptian J. Nutrition and feeds, 1 (2): 73-85.

تأثير مستويات الطاقة علي مظاهر الأداء الإنتاجي والتناسلي في إناث الجاموس.

$$
\begin{aligned}
& \text { حمدي المطراوي دياب * ـ مختار عبدالعظيم أحمد سرحان*** } \\
& \text { * " معهز بحوث الإنتاج الحيواني - مركز البحوث الززاعية - وزارة الزراعة -مصر. }
\end{aligned}
$$

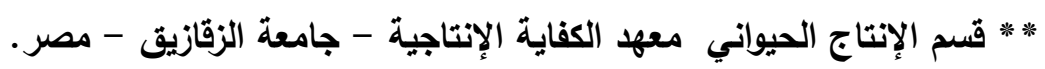

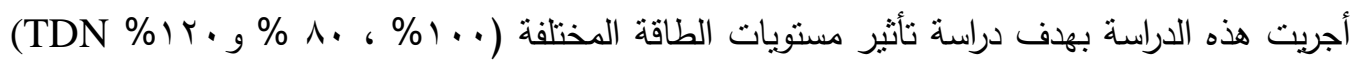

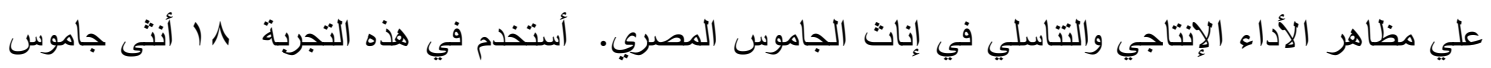

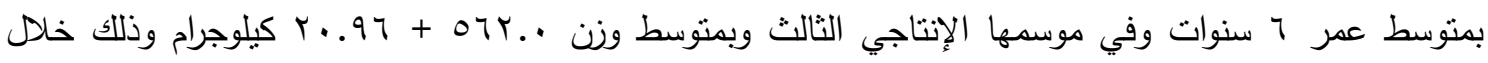

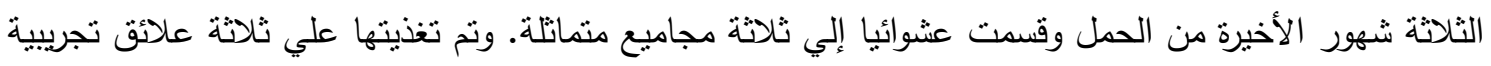

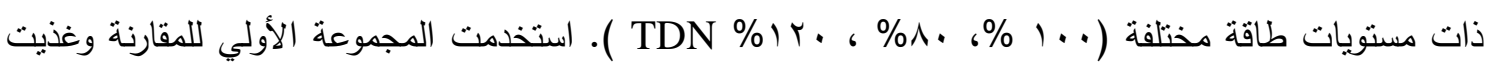

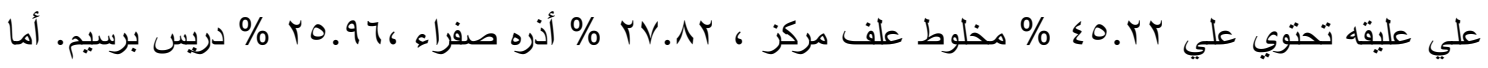

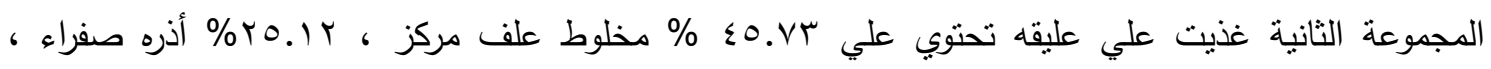

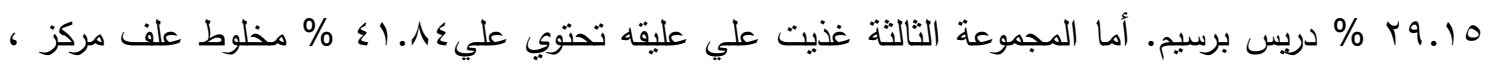

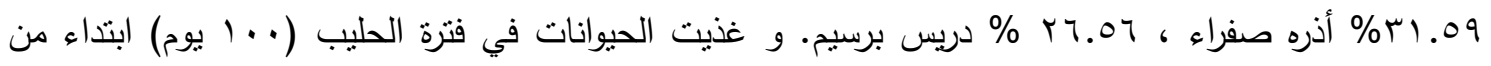
اليوم الـ •ـ بعد الولادة علي علائق حسب الوزن وكمية إنتاج اللبن طبقا لمقررات (Kearl, 1982). وأجريت

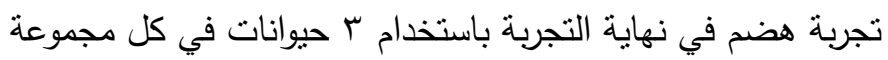

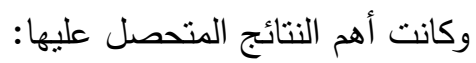




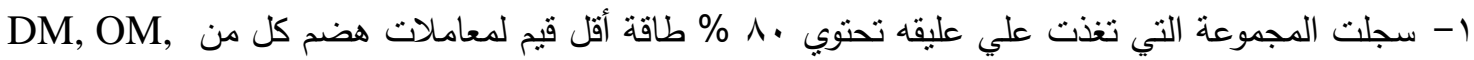
CF, EE and NFE كانت الفروق بين المجموعات التجريبية في القيم الغذائية (TDN, DCP) غير معنوية. r- سجلت الحيوانات التي تغذت علي عليقه تحنوي • Y 1 \% طاقة أعلي متوسط لوزن العجول عند الولادة

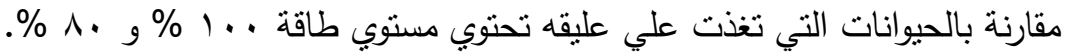

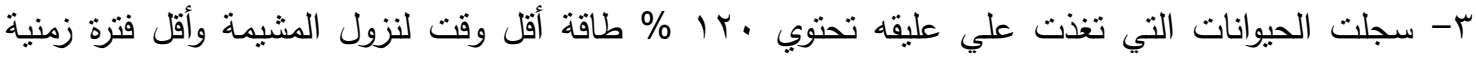
لتماثل قرني الرحم واقل عدد من التلقيحات اللازمة للحمل مقارنة بالحيوانات التي تغذت علي عليقه تحنوي

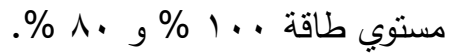
ع- كانت الفترة من الولادة وعودة الرحم لوضعه الطبيعي والفترة بين الولادة وأول شياع ملحوظ والفترة بين ولادنين للحيوانات التي تغذت علي عليقه تحتوي • با \% طاقة أقصر معنويا علي مستوي احتمال ٪\% من الحيوانات

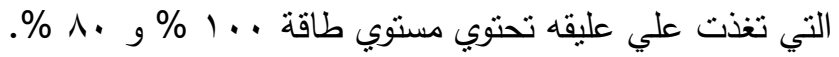

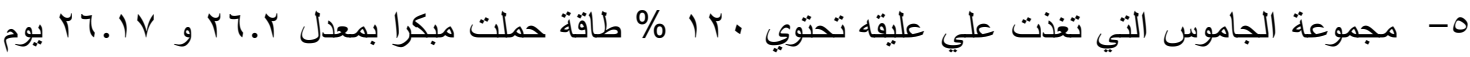

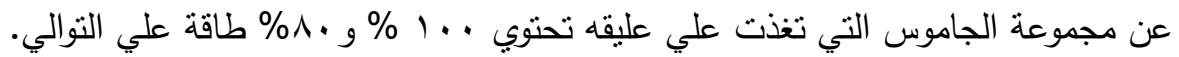
צ- كان إنتاج اللبن والدهن والبروتين واللاكتوز والمواد الصلبة الكلية والمواد الصلبة الغير دهنية ككمية إنتاج

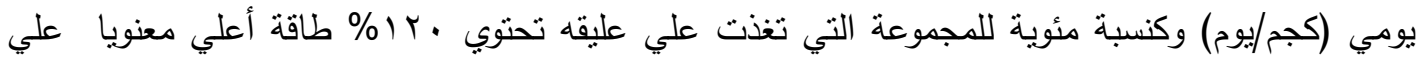

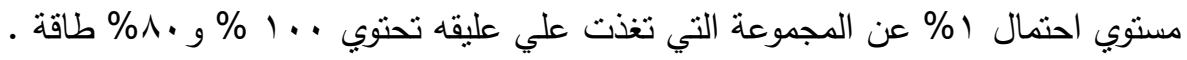
V- كان مستوي البروجسترون والأستروجين أعلي معنويا في سيرم دم الحيوانات التي تغذت علي عليقه تحتوي

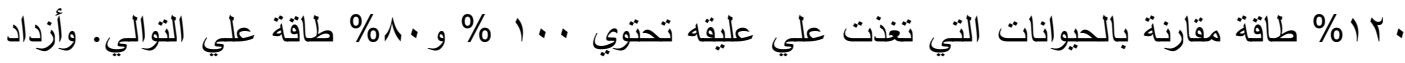

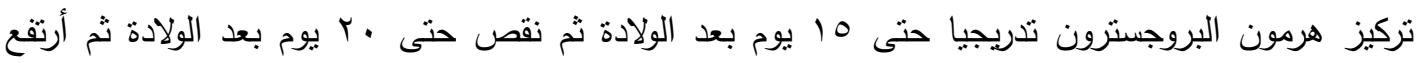

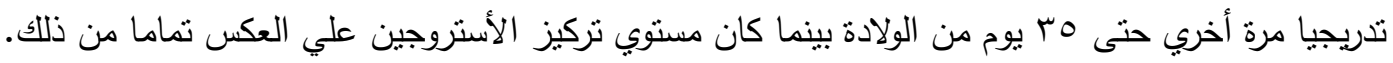

من هذه الدراسة ينصح بأنه يمكن أن تكون علائق الجاموس خلال الثهور الأخيرة من الحمل والجاموس الحلاب تحتوي علي طاقة ـ r ا \% حيث أن هذه النسبة أعطت أفضل نتائج من ناحية القيم الغذائية وإنتاج اللبن بدون أي تأثثرات سلبية علي الأداء التتاسلي والإنتاجي • 